\title{
THE INFLUENCE OF CUSTOMERS COMMUNICATION BEHAVIOUR IN THE IMPLEMENTATION OF 21CINEPLEX VIRAL MARKETING USING THE SOCIAL NETWORKING SITE FACEBOOK
}

\author{
Meyliana \\ Department of Information Systems \\ School of Information Systems \\ Bina Nusantara University \\ Jakarta 11480, Indonesia \\ Email: meyliana@binus.edu
}

\author{
Henry Antonius E. W. \\ Department of Information System
School of Information Systems \\ Bina Nusantara University \\ Jakarta 11480, Indonesia \\ Email: haew@binus.edu
}

\author{
Stephen W. Santoso \\ Department of Information Systems \\ School of Information Systems \\ Bina Nusantara University \\ Jakarta 11480, Indonesia \\ Email: ssantoso@binus.edu
}

\begin{abstract}
Application of viral marketing through social networking sites will greatly help companies in saving high marketing costs since companies do not have to give financial incentive to internet users or customers who voluntarily forward the information about the companies. Good marketing communication strategy will increase the company's branding and enable good interaction between customers and companies. This study focuses on whether the customer communication behavior has a relationship and a significant impact on forwarding online content and whether the curiosity variable has a relationship and a significant impact on the variable of consumption of online content in the application of Viral Marketing. The methodology used is interpersonal communication model adopted from FIRO theory, which consists of the following variables: inclusion-need to belong, inclusion-individuation, affection-altruism, controlpersonal growth, and consumption of online content, toward the online content forwarding variable; and also the curiosity variable towards the consumption of online content variable, where the hypothesis was tested by the correlation and regression analysis. The test results based on correlation analysis show that all $\mathrm{H}_{1}$ hypotheses (have relation) are received; and based on regression analysis, all $\mathrm{H}_{1}$ hypotheses (effect) are received, although the value of the correlation coefficient $r$ and the effect is less significant (small).
\end{abstract}

Keywords: customer communication behavior; FIRO; viral marketing; facebook

Abstrak-Penerapan viral marketing melalui situs jejaring sosial akan sangat membantu perusahaan dalam menghemat biaya pemasaran yang tinggi, karena perusahaan tidak perlu lagi memberikan insentif finansial kepada pengguna internet atau pelanggan yang dengan sukarela menyampaikan informasi perusahaan. Strategi komunikasi pemasaran yang baik akan meningkatkan merek dagang perusahaan dan memungkinkan komunikasi yang baik di antara para pelanggan dan perusahaan. Penelitian ini berfokus pada apakah perilaku komunikasi pelanggan memiliki hubungan dan dampak yang signifikan terhadap forwarding online content dalam penerapan viral marketing. Metode yang digunakan adalah model komunikasi antar personal yang diadopsi dari teori FIRO, yang terdiri dari beberapa variabel sebagai berikut: inclusion-need to belong, inclusionindividuation, affection-altruism, control-personal growth, dan consumption of online content terhadap forwarding online content dan variabel curiosity terhadap consumption of online content yang hipotesisnya diuji berdasarkan analisis korelasi dan analisis regresi. Berdasarkan analisis korelasi, hasil tes memperlihatkan bahwa semua hipotesis $\mathrm{H}_{1}$ (memiliki hubungan) diterima; dan berdasarkan analisis regresi, semua hipotesis $\mathrm{H}_{1}$ (berpengaruh) diterima, walaupun nilai koefisien korelasi $r$ dan besar pengaruhnya kurang signifikan (kecil).

Kata-kata kunci: perilaku komunikasi pelanggan; FIRO; viral marketing; facebook

\section{INTRODUCTION}

Nowadays, Internet has become the most complete source of information. People will search for news and information, free entertainment, separated friends or relatives and many other activities on Internet. This makes Internet greatly affecting people's way of thinking and behavior in modern time.

Significant changes have also been undertaken in the area of the marketing strategy of companies. One of the marketing concepts that relies heavily on Internet is known as e-marketing [1-4]. 
Currently, e-marketing strategy has shifted into more personalized marketing communication and has been strongly influenced by the online environment, namely viral marketing. Viral marketing is generally initiated by marketers through some electronic contents such as videos or mini sites, which generally aim to build branding [5-10].

The power of viral marketing relies heavily on the communication behavior of customers [11-13]. A very important factor in viral marketing is the motivation of Internet users to forward the received electronic content (even only in the URL form). Understanding the motivation of Internet users who want to forward the online content is very important since the decision of forwarding the content is a voluntary work. In other words, marketers do not have to pay Internet users to continue its online content. Forwarding information to a large group of internet users may lead to extensive dissemination of information (viral), which is often known as e-WOM. In their study, Ref. [11] utilized the research framework adopted from interpersonal communication that is based on the theory of Fundamental Interpersonal Relations Orientation (FIRO) [14], which consists of inclusion (the need to be part of a group/need to get attention), affection (showing appreciation and concern for others), and control (the need to use force in the social environment).

In addition to using FIRO theory, Ref. [11] added a few variables into their study; thus, the total number of variables became seven variables, namely, inclusionneed to belong [14, 15], inclusion-individuation [1417], affection-altruism [14, 18, 19], control-personal growth $[14,20]$, curiosity [21], consumption of online content [22] and forwarding online content [23, 24].

As the leading company and pioneer in the entertainment service provider, 21Cineplex has customers whom mainly are teenagers and adults, and they are familiar with new technological development. For this reason, 21Cineplex has a great concern on the use of electronic marketing (e-marketing), especially through social networking sites.

This study focuses on the customer communication behavior and viral marketing via Facebook, a dominant social networking site, for the case of 21Cineplex. More specifically, the study intends to determine the extent of the influence of customer communication behavior in the application of the 21Cineplex viral marketing using Facebook. The benefits of this research are to provide information to $21 \mathrm{Cineplex}$, and the like in a more general case, about important aspects that affect the application of viral marketing and recommendations to improve the use of viral marketing.

\section{METHODS}

The study is focused on how the customer communication behavior affects the intention to recommend the customer peers. The related variables are adopted from the study of Ref. [11]. The customer communication behavior is described by the variables: inclusion-need to belong, inclusion-individuation, affection-altruism, control-personal growth, and consumption of online content. The study also adds an additional variable in the form of customer curiosity. The interaction of those variables is graphically shown in Fig. 1.

The study is performed following the steps depicted in Fig. 2. The data are collected from 21Cineplex customers.

The relations depicted Fig. 1 are further expressed in term of the research hypotheses. In total, we establish 12 hypotheses where the first six will be evaluated by means of the correlation analysis. The second six hypotheses will be evaluated by means of the regression analysis. The detail of each variable is provided in Table I.

Those 12 hypotheses are of the following:

Hypothesis $1: \mathrm{H}_{0}$ : There is no significant relationship between Inclusion-Need to belong to the Forwarding Online Content, and $\mathrm{H}_{1}$ : There is a significant

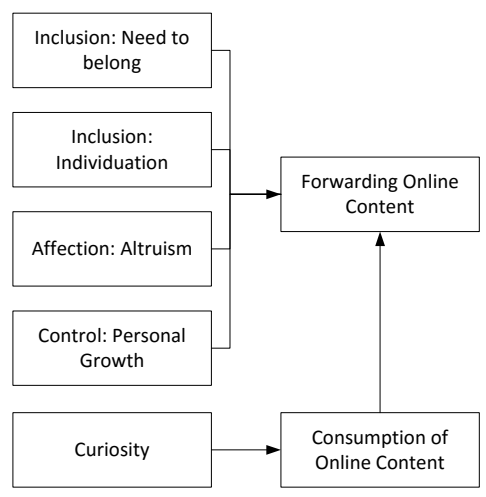

Fig. 1. The framework of the study.

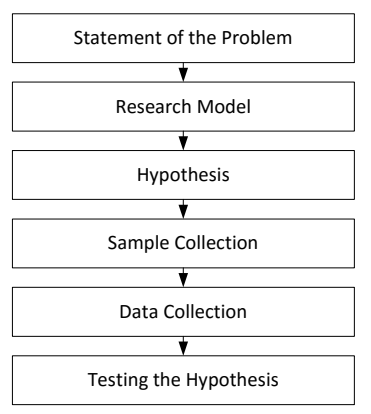

Fig. 2. Research methodology [25] 
TABLE I

DESCRIPTION OF VARIABLES AND SUB-VARIABLES

\begin{tabular}{|c|c|c|}
\hline Variable & Sub-Variable & Description \\
\hline $\begin{array}{l}\text { Inclusion: Need to } \\
\text { belong }\left(X_{1}\right)\end{array}$ & $\begin{array}{l}\text { Acceptance }\left(X_{1.1}\right) \\
\text { Timeliness }\left(X_{1.2}\right) \\
\text { Friendly }\left(X_{1.3}\right) \\
\text { Carelessness }\left(X_{1.4}\right) \\
\text { Partnership }\left(X_{1.5}\right) \\
\text { Participation }\left(X_{1.6}\right) \\
\text { Goodness }\left(X_{1.7}\right)\end{array}$ & $\begin{array}{l}\text { Receiving information through a link from a friend } \\
\text { Receiving information at the expected time } \\
\text { Liking the links on their wall } \\
\text { Getting the attention of a friend via a provided link } \\
\text { Strengthen relationships with friends } \\
\text { Understand the desire of friends to participate } \\
\text { Receiving useful information }\end{array}$ \\
\hline $\begin{array}{l}\text { Inclusion: } \\
\text { Individua- } \\
\text { tion }\left(X_{2}\right)\end{array}$ & $\begin{array}{l}\text { Purpose }\left(X_{2.1}\right) \\
\text { Innovativeness }\left(X_{2.2}\right) \\
\text { Demographic }\left(X_{2.3}\right)\end{array}$ & $\begin{array}{l}\text { Understanding the receiver desires for information upon submission } \\
\text { Disseminate information in a way that is unique/innovative } \\
\text { Knowing sender information clearly }\end{array}$ \\
\hline $\begin{array}{l}\text { Affection: } \\
\text { Altruism } \\
\left(X_{3}\right)\end{array}$ & $\begin{array}{l}\text { Product Involvement }\left(X_{3.1}\right) \\
\text { Message Intrigue }\left(X_{3.2}\right) \\
\text { Other Involvement }\left(X_{3.3}\right) \\
\text { Message Involvement }\left(X_{3.4}\right) \\
\text { Vengeance }\left(X_{3.5}\right) \\
\text { Dissonance Reduction }\left(X_{3.6}\right)\end{array}$ & $\begin{array}{l}\text { Trust the sender comments as a trusted source of information } \\
\text { Understand the messages sent by informers } \\
\text { Feel the information received will be useful for others } \\
\text { Trusting the received information especially if the information has } \\
\text { many comments } \\
\text { Understanding of the disappointment of the providers } \\
\text { Doing something triggered by received information }\end{array}$ \\
\hline $\begin{array}{l}\text { Control: } \\
\text { Personal } \\
\text { Growth } \\
\left(X_{4}\right)\end{array}$ & $\begin{array}{l}\text { Decide }\left(X_{4.1}\right) \\
\text { Self-Confidence }\left(X_{4.2}\right) \\
\text { Transition }\left(X_{4.3}\right) \\
\text { Pattern }\left(X_{4.4}\right) \\
\text { Balance }\left(X_{4.5}\right)\end{array}$ & $\begin{array}{l}\text { Deciding to do something after receiving information } \\
\text { Performing something because the transmitted information is very } \\
\text { supportive } \\
\text { Experiencing significant change by sharing information } \\
\text { Benefiting from transmitted information } \\
\text { Getting complete information from multiple perspectives }\end{array}$ \\
\hline $\begin{array}{l}\text { Curiosity } \\
\left(X_{5}\right)\end{array}$ & $\begin{array}{l}\text { Exploration }\left(X_{5.1}\right) \\
\text { Absorption }\left(X_{5.2}\right) \\
\text { Novelty }\left(X_{5.3}\right) \\
\text { Complexity }\left(X_{5.4}\right)\end{array}$ & $\begin{array}{l}\text { Getting more detailed information from links } \\
\text { Providing additional relevant information of interest } \\
\text { Gaining new insights from received information } \\
\text { Obtaining complete information based on additional information from } \\
\text { other information providers }\end{array}$ \\
\hline $\begin{array}{l}\text { Consumption } \\
\text { of Online } \\
\text { Content }(Y)\end{array}$ & $\begin{array}{l}\text { Forwarding Information }\left(Y_{1}\right) \\
\text { Finding Support }\left(Y_{2}\right) \\
\text { Consumer Needs }\left(Y_{3}\right)\end{array}$ & $\begin{array}{l}\text { The level of frequency of forwarding received information } \\
\text { The level of frequency of searching further information on the Internet } \\
\text { The level of frequency of using other substituting media }\end{array}$ \\
\hline $\begin{array}{l}\text { Forwarding } \\
\text { Online } \\
\text { Content } \\
(Z)\end{array}$ & $\begin{array}{l}\text { Interpersonal Communication }\left(Z_{1}\right) \\
\text { Sharing Link }\left(Z_{2}\right) \\
\text { Email/Instant Messaging }\left(Z_{3}\right) \\
\text { e-WOM }\left(Z_{4}\right) \\
\text { Specific URL }\left(Z_{5}\right) \\
\text { Update Links }\left(Z_{6}\right) \\
\text { Feedback }\left(Z_{7}\right)\end{array}$ & $\begin{array}{l}\text { The level of frequency of using personal communication media } \\
\text { The level of frequency of sharing links } \\
\text { The level of frequency of opening email } \\
\text { The level of frequency of providing a response (leave a comment) } \\
\text { The level of frequency of adding links on a thread or status } \\
\text { The level of frequency of updating the link } \\
\text { The level of frequency of providing feedback to the link of information } \\
\text { providers }\end{array}$ \\
\hline
\end{tabular}

relationship between Inclusion-Need to belong to the Forwarding Online Content.

Hypothesis 2: $\mathrm{H}_{0}$ : There is no significant relationship between Inclusion-individuation with Forwarding Online Content, and $\mathrm{H}_{1}$ : There is a significant relationship between Inclusion-individuation with Forwarding Online Content.

Hypothesis 3: $\mathrm{H}_{0}$ : There is no significant relationship between Affection-Altruism with Forwarding Online Content, and $\mathrm{H}_{1}$ : There is a significant relationship between Affection-Altruism with Forwarding Online Content.

Hypothesis 4: $\mathrm{H}_{0}$ : There is no significant relationship between the Control-Personal Growth with Forwarding, and $\mathrm{H}_{1}$ : There is a significant relationship between the Control-Personal Growth with Forwarding Online Content.

Hypothesis 5: $\mathrm{H}_{0}$ : There is no significant relationship between Curiosity with Consumption of Online Content, and $\mathrm{H}_{1}$ : There is a significant relationship between Curiosity with Consumption of Online Content.

Hypothesis 6: $\mathrm{H}_{0}$ : There is no significant effect between Consumption of Content Online with Forwarding Online Content, and $\mathrm{H}_{1}$ : There is a significant relationship between Consumption of Content Online with Forwarding Online Content.

Hypothesis 7: $\mathrm{H}_{0}$ : There is no significant effect between Inclusion-Need to belong to the Forwarding Online Content, and $\mathrm{H}_{1}$ : There is a significant relationship between Inclusion-Need to belong to the 
Forwarding Online Content.

Hypothesis 8: $\mathrm{H}_{0}$ : There is no significant effect between Inclusion-individuation against Forwarding Online Content, and $\mathrm{H}_{1}$ : There is a significant relationship between Inclusion-individuation against Forwarding Online Content.

Hypothesis 9: $\mathrm{H}_{0}$ : There is no significant influence of Affection-Altruism against Forwarding Online Content, and $\mathrm{H}_{1}$ : There is a significant relationship between Affection-Altruism against Forwarding Online Content.

Hypothesis 10: $\mathrm{H}_{0}$ : There is no significant effect between Control-Personal Growth on Forwarding Online Content, and $\mathrm{H}_{1}$ : There is a significant relationship between Control-Personal Growth on Forwarding Online Content.

Hypothesis 11: $\mathrm{H}_{0}$ : There is no significant effect between Curiosity against Consumption of Content Online, and $\mathrm{H}_{1}$ : There is a significant relationship between Curiosity against Consumption of Content Online.

Hypothesis $12: \mathrm{H}_{0}$ : There is no significant effect between Consumption of Online Content on Forwarding Online Content, and $\mathrm{H}_{1}$ : There is a significant relationship between Consumption of Online Content on Forwarding Online Content.

It is generally known that the relationship between an independent variable and a dependent variable can be measured by means of the correlation analysis. In this analysis, a coefficient, called the correlation coefficient, is computed by the equation [26]:

$$
r_{x y}=\frac{n \Sigma x_{i} y_{i}-\left(\Sigma x_{i}\right)\left(\Sigma y_{i}\right)}{\sqrt{\left[n \Sigma x_{i}^{2}-\left(\Sigma x_{i}\right)^{2}\right]\left[n \Sigma y_{i}^{2}-\left(\Sigma y_{i}\right)^{2}\right]}}
$$

where $r_{x y}$ denotes the correlation coefficient, $x_{i}$ is the $i$-value of $x$ variable, $y_{i}$ is the $i$-value of the $y$ variable, and $n$ is the sample size.

A regression analysis can be used to quantify the amount of an independent variable affects the dependent variable. The regression equation in its simplest form is written:

$$
y=a+b x,
$$

where $y$ is the dependent variable, $x$ is the independent variable, and $a$ and $b$ are the regression coefficients.

An increase or decrease in the dependent variable depends on the independent variable. When the $\mathrm{b}(+)$ then go up, and when the (-) then a decline [26].

The data are obtained via questionnaire where the respondents provide their responses in the Likert scale with the ordinal data type. The utilized scales are 1,2, 3,4 , and 5. Those responses are transformed into the interval data type using the method of successive intervals [27]. The transformation procedure is explained in Table II.

TABLE II

THE TRANSFORMATION PROCESS THAT WAS PLACED INTO IN INTERVAL [27].

1) For each question, calculate the frequency response of each category (choice answers).

2) Based on the frequency, each category is calculated in proportion.

3) Of proportion obtained, calculate the cumulative proportion for each category.

4) Determine the value $Z$ limit for each category Calculate the value scale (the average interval) for each category by the equation

Scale $=\frac{\text { Density of lower limit }- \text { Density of upper limit }}{\text { Area under upper limit }- \text { Area under lower limit }}$

Calculate the score (the value of the transformation) for each category by the equation score $=$ scale value $+\mid$ scale Valuemin $\mid+1$

The population in this study are limited to all active students at Bina Nusantara University in Jakarta, Indonesia. Furthermore, those students will be referred as Binusian. The academic years of the students are 2011, 2012, 2013, and 2014 with the total student size of 19101 students. The detail can be seen in the Table III.

According to Isaac and Michael's formula [26], for the population size of 19101, the sample size should be around 395 students for 5\% level of error. The collected data are analyzed using SPSS 17.0 software package.

The respondents provide their responses related to a number of the variables of interest: Inclusion-Need to belong $\left(X_{1}\right)$, Inclusion-individuation $\left(X_{2}\right)$, AffectionAltruism $\left(X_{3}\right)$, Control-Personal Growth $\left(X_{4}\right)$, Curiosity $\left(X_{5}\right)$, Consumption of Online Content $(Y)$, and Forwarding Online Content $(Z)$. Table IV presents the provided questions and related sub-variables [28].

TABLE III

THE DISTRIBUTION OF THE ACTIVE STUDENTS AT BINA NUSANTARA UNIVERSITY.

\begin{tabular}{cc}
\hline Binusian & Number of Active Students \\
\hline 2011 & 2726 \\
2012 & 5125 \\
2013 & 5377 \\
2014 & 5873 \\
\hline
\end{tabular}


TABLE IV

LIST OF VARIABLES AND THE RELATED QUESTIONS.

Inclusion: Need-to-belong $\left(X_{1}\right)$

\begin{tabular}{|c|c|}
\hline$X_{1.1}$ & I receive information about the latest movies via links (URL) of 21 Cineplex movies from friends \\
\hline$X_{1.2}$ & $\begin{array}{l}\text { I receive information about the latest movies via links (URL) of } 21 \text { Cineplex latest movies from friends at the appropriate } \\
\text { time }\end{array}$ \\
\hline$X_{1.3}$ & I like the design of the links (URL) of 21Cineplex movies that appear on my wall \\
\hline$X_{1.4}$ & I receive the attention from friends when receiving movie information from the links (URL) of 21Cineplex movies \\
\hline$X_{1.5}$ & $\begin{array}{l}\text { I strengthen my relationships with friends when receiving movie information through links (URL) of 21Cineplex movies } \\
\text { from friends }\end{array}$ \\
\hline$X_{1.6}$ & I know my friend want me to watch movies through movie information from the links (URL) of 21Cineplex movies \\
\hline$X_{1.7}$ & I receive useful information via links (URL) of 21Cineplex movies sent by a friend \\
\hline \multicolumn{2}{|r|}{ Inclusion: Individuation $\left(X_{2}\right)$} \\
\hline$X_{2.1}$ & I think my friend understand my preferred movie information when sending the link (URL) of 21Cineplex movies \\
\hline$X_{2.2}$ & I know my friend want me to watch movies through movie information from the links (URL) of 21Cineplex movies \\
\hline$X_{2.3}$ & I receive useful information via links (URL) of 21Cineplex movies sent by a friend \\
\hline \multicolumn{2}{|r|}{ Affection: Altruism $\left(X_{3}\right)$} \\
\hline$X_{3.1}$ & $\begin{array}{l}\text { I believe the comments from friends who sends updated information via links (URL) and they indeed recommend to } \\
\text { watch the movies }\end{array}$ \\
\hline$X_{3.2}$ & I understand the message sent by a friend via links (URL) of 21Cineplex movies \\
\hline$X_{3.3}$ & $\begin{array}{l}\text { I think the information that is sent by a friend via links (URL) of 21Cineplex movies is also very useful for my other } \\
\text { friends }\end{array}$ \\
\hline$X_{3.4}$ & $\begin{array}{l}\text { I am more convinced by the message that is sent via links (URL) of } 21 \text { Cineplex movies when there are plenty of other } \\
\text { friends who participate by commenting on links (URL) of 21Cineplex movie }\end{array}$ \\
\hline$X_{3.5}$ & $\begin{array}{l}\text { I know the disappointment of friends about a particular movie from their commentary on links (URL) of 21Cineplex } \\
\text { movies sent to me }\end{array}$ \\
\hline$X_{3.6}$ & I often watch the movie since I am curious with the comments from friends in the link (URL) of 21Cineplex movies \\
\hline \multicolumn{2}{|r|}{ Control: Personal Growth $\left(X_{4}\right)$} \\
\hline$X_{4.1}$ & I can decide whether or not I am going to watch a particular movie after I receive links (URL) of 21Cinemax movies \\
\hline$X_{4.2}$ & $\begin{array}{l}\text { I increasingly want to watch this movie because of the supportive comments of friends on links (URL) of 21Cineplex } \\
\text { movies }\end{array}$ \\
\hline$X_{4.3}$ & I experience a significant change through the sharing information by sending links (URL) of 21Cineplex movie \\
\hline$X_{4.4}$ & $\begin{array}{l}\text { I could have a benefit from the links (URL) of } 21 \text { Cineplex movies sent by a friend, so I would do the same good things } \\
\text { for others }\end{array}$ \\
\hline$X_{4.5}$ & $\begin{array}{l}\text { I get the complete information by reading comments of friends via links (URL), so I know for sure about good or bad } \\
\text { movies }\end{array}$ \\
\hline \multicolumn{2}{|r|}{ Curiosity $\left(X_{5}\right)$} \\
\hline$X_{5.1}$ & I can click the links (URL) of 21Cineplex movies sent to find out more information about the movies \\
\hline$X_{5.2}$ & I will comment on the links (URL) sent especially for movies that are my favorites \\
\hline$X_{5.3}$ & I gain new insights from the links (URL) of 21Cineplex movies sent by a friend \\
\hline$X_{5.4}$ & I get a lot of information about the movie of links (URL) through the given comments \\
\hline \multicolumn{2}{|r|}{ Consumption of Online Contents $(Y)$} \\
\hline$Y_{1}$ & How often do you forward the information you have on your Facebook wall to another friend? \\
\hline$Y_{2}$ & How often do you seek further information about the latest movies by googling/browsing on the internet? \\
\hline$Y_{3}$ & How often do you watch movies on digital media (such as YouTube, DVD, etc.) in the sense of not going to the cinema? \\
\hline \multicolumn{2}{|r|}{ Forwarding Online Content $(Z)$} \\
\hline$Z_{1}$ & $\begin{array}{l}\text { How often do you use messenger chat on Facebook? How often do you log in to Facebook? How often do you open } \\
\text { 21Cineplex website? }\end{array}$ \\
\hline$Z_{2}$ & $\begin{array}{l}\text { Have you ever sent a link (URL) about } 21 \text { Cineplex that contains information about the latest movies? If yes, how often } \\
\text { do you send the links (URL)? }\end{array}$ \\
\hline$Z_{3}$ & How often do you open the inbox on Facebook? \\
\hline$Z_{4}$ & $\begin{array}{l}\text { How often do you get a response (comment) and a reply to the response of another person (comment) on the Facebook } \\
\text { wall? }\end{array}$ \\
\hline$Z_{5}$ & How often to you include a link (URL) in the thread or the status that you create on Facebook? \\
\hline$Z_{6}$ & How often do you change or update links (URL) in the thread or the status that you create? \\
\hline$Z_{7}$ & How often do you give feedback or input to friends who have sent a link (URL) to you? \\
\hline
\end{tabular}




\section{RESULTS AND DISCUSSION}

As previously described, questionnaires are distributed to obtain the responses regarding the customer communication behavior and the intention to recommend the customer peers. The number of the distributed and returned questionnaires is tabulated in Table V.

Firstly, we evaluate the validity and reliability of the responses by evaluating the correlation $r$ count and the Cronbach's $\alpha$. In general, if the correlation $r$ count is greater than the tabulated critical value, the response is consider to be valid. The Cronbach's $\alpha$ coefficient is compared to the critical $r$ table. The question is considered valid if the Cronbach's $\alpha$ is greater. For $n$ of 30 and 5\% error level, the value of $r$ table is 0.361 . The results are presented in Tables VI and VII.

The results of the correlation test are shown in Table VIII. We note that the $r$ table is 0.098 . Thus,

TABLE V

DESCRIPTION OF THE NUMBER OF QUESTIONNAIRES.

\begin{tabular}{ccc}
\hline Binusian & \multicolumn{2}{c}{ Questionnaires } \\
\cline { 2 - 3 } & Disseminated & Collected \\
\hline 2011 & 80 & 60 \\
2012 & 125 & 106 \\
2013 & 125 & 111 \\
2014 & 125 & 118 \\
\hline
\end{tabular}

TABLE VI

VALIDITY TEST RESULTS

\begin{tabular}{lcc}
\hline Variable & Sub-variable & \multicolumn{2}{c}{ Status } \\
\cline { 3 - 3 } & & Valid \\
& & $\times$ \\
\hline Inclusion-Need to belong $\left(X_{1}\right)$ & $X_{1.1}-X_{1.7}$ & $\times$ \\
Inclusion-Individuation $\left(X_{2}\right)$ & $X_{2.1}-X_{2.3}$ & $\times$ \\
Affection-Altruism $\left(X_{3}\right)$ & $X_{3.1}-X_{3.6}$ & $\times$ \\
Control-Personal Growth $\left(X_{4}\right)$ & $X_{4.1}-X_{4.5}$ & $\times$ \\
Curiosity $\left(X_{5}\right)$ & $X_{5.1}-X_{5.3}$ & $\times$ \\
Consumption of Online Con- & $Y_{1}-Y_{3}$ & $\times$ \\
tent $(Y)$ & & \\
Forwarding Online Content & $Z_{1}-Z_{7}$ & $\times$ \\
$(Z)$ & & \\
\hline
\end{tabular}

TABLE VII

RELIABILITY TEST RESULTS.

\begin{tabular}{lcc}
\hline Variable & Reliable & Not Reli. \\
\hline Inclusion: Need-to-belong $\left(X_{1}\right)$ & $\times$ \\
Inclusion: Individuation $\left(X_{2}\right)$ & $\times$ \\
Affection: Altruism $\left(X_{3}\right)$ & $\times$ \\
Control: Personal Growth $\left(X_{4}\right)$ & $\times$ \\
Curiosity $\left(X_{5}\right)$ & $\times$ \\
Consumption of Online Content $(Y)$ & $\times$ \\
Forwarding Online Content $(Z)$ & $\times$ \\
\hline
\end{tabular}

TABLE VIII

CORRELATION TEST RESUlts.

\begin{tabular}{ccc}
\hline Hypothesis & Pearson's Correlation & Accepted Hypothesis \\
\hline 1 & 0.129 & $\mathrm{H}_{1}$ \\
2 & 0.120 & $\mathrm{H}_{1}$ \\
3 & 0.129 & $\mathrm{H}_{1}$ \\
4 & 0.109 & $\mathrm{H}_{1}$ \\
5 & 0.123 & $\mathrm{H}_{1}$ \\
6 & 0.134 & $\mathrm{H}_{1}$ \\
\hline
\end{tabular}

TABLE IX

REGRESSION TEST RESULTS

\begin{tabular}{cccc}
\hline Hypothesis & $R^{2}$ & Influence Amount $(\%)$ & Accepted Hypo. \\
\hline 7 & 0.017 & 1.7 & $\mathrm{H}_{1}$ \\
8 & 0.014 & 1.4 & $\mathrm{H}_{1}$ \\
9 & 0.017 & 1.7 & $\mathrm{H}_{1}$ \\
10 & 0.012 & 1.2 & $\mathrm{H}_{1}$ \\
11 & 0.015 & 1.5 & $\mathrm{H}_{1}$ \\
12 & 0.018 & 1.8 & $\mathrm{H}_{1}$ \\
\hline
\end{tabular}

all correlation values are bigger than the $r$ table. In addition, the values of the significance level are below 0.05 . Hence, we accept $\mathrm{H}_{1}$.

The result of the regression analysis is shown in Table IX. For all cases, the computed level of significances are very small (significantly smaller than 0.05). Thus, we accept all $\mathrm{H}_{1}$ hypotheses. The amount of influence of each variable is shown in the column labeled with 'Influence Amount'.

\section{CONCLUSIONS}

A weak but positive correlation exists between the consumption and forwarding of the online contents and the need-to-belong, inclusion-individuation, afflectionaltruism, and the control of the personal growth. In addition, a similar correlation also exists between curiosity and the consumption of the online contents. A weak positive influence exists between the customer communication behavior, as described by variables: the need-to-belong, control personal growth, and the consumption of the online content, on the forwarding online content attitude. Thus, this study recommends 21Cineplex to improve features in such a way that their customers are willing to forward 21Cineplex's information through social networking sites. The information should be designed uniquely and innovative to maintain customer interests. In addition, 21Cineplex should also provide the movie recommendations and testimonial through social networking websites. Additional variables for consideration may be of interest for future works to produce a more holistic recommendation. 


\section{REFERENCES}

[1] J. Strauss and R. Frost, E-Marketing, sixth edition ed. New Jersey: Pearson, 2012.

[2] R. Chitturi, R. Raghunathan, and V. Mahajan, "Delight by design: The role of hedonic versus utilitarian benefits," Journal of Marketing, vol. 72, no. 3, pp. 48-63, 2008.

[3] K. Vance, W. Howe, and R. P. Dellavalle, "Social internet sites as a source of public health information," Dermatologic clinics, vol. 27, no. 2, pp. 133-136, 2009.

[4] I. Mohr, "Buzz marketing for movies," Business Horizons, vol. 50, no. 5, pp. 395-403, 2007.

[5] D. J. Watts, J. Peretti, and M. Frumin, Viral marketing for the real world. Harvard Business School Publishing, 2007.

[6] R. E. Moore, "From genericide to viral marketing: on brand," Language \& Communication, vol. 23, no. 3, pp. 331-357, 2003.

[7] J. A. Chevalier and D. Mayzlin, "The effect of word of mouth on sales: Online book reviews," Journal of marketing research, vol. 43, no. 3, pp. 345-354, 2006.

[8] A. M. Kaplan and M. Haenlein, "The britney spears universe: Social media and viral marketing at its best," Business Horizons, vol. 55, no. 1, pp. 27-31, 2012.

[9] C. Swanepoel, A. Lye, and R. Rugimbana, "Virally inspired: A review of the theory of viral stealth marketing," Australasian Marketing Journal (AMJ), vol. 17, no. 1, pp. 9-15, 2009.

[10] K. I. Zernigah and K. Sohail, "Consumers' attitude towards viral marketing in pakistan," Management \& Marketing, vol. 7, no. 4, p. 645, 2012.

[11] J. Y. Ho and M. Dempsey, "Viral marketing: Motivations to forward online content," Journal of Business Research, vol. 63, no. 9, pp. 10001006, 2010.

[12] B. G. Southwell, J. S. Slater, A. J. Rothman, L. M. Friedenberg, T. R. Allison, and C. L. Nelson, "The availability of community ties predicts likelihood of peer referral for mammography: Geographic constraints on viral marketing," Social science \& medicine, vol. 71, no. 9, pp. 16271635, 2010.

[13] S. Casswell, "Alcohol brands in young peoples'everyday lives: New developments in marketing," Alcohol and Alcoholism, vol. 39, no. 6, pp. 471-476, 2004.

[14] W. C. Schutz, FIRO: A three-dimensional theory of interpersonal behavior. Rinehart \& Winston, 1958.
[15] A. J. Flanagin and M. J. Metzger, "Internet use in the contemporary media environment," Human communication research, vol. 27 , no. 1 , pp. $153-$ 181, 2001.

[16] C. M. Chung and P. R. Darke, "The consumer as advocate: Self-relevance, culture, and wordof-mouth," Marketing Letters, vol. 17, no. 4, pp. 269-279, 2006.

[17] V. L. Vignoles, X. Chryssochoou, and G. M. Breakwell, "The distinctiveness principle: Identity, meaning, and the bounds of cultural relativity," Personality and Social Psychology Review, vol. 4, no. 4, pp. 337-354, 2000.

[18] L. L. Price, L. F. Feick, and A. Guskey, "Everyday market helping behavior,' Journal of Public Policy \& Marketing, vol. 1, pp. 255-266, 1995.

[19] J. E. Phelps, R. Lewis, L. Mobilio, D. Perry, and N. Raman, "Viral marketing or electronic word-of-mouth advertising: Examining consumer responses and motivations to pass along email," Journal of advertising research, vol. 44, no. 04, pp. 333-348, 2004.

[20] C. Robitschek, "Personal growth initiative: The construct and its measure," Measurement and Evaluation in Counseling and Development, vol. 30, no. 4, p. 183, 1998.

[21] T. B. Kashdan, P. Rose, and F. D. Fincham, "Curiosity and exploration: Facilitating positive subjective experiences and personal growth opportunities," Journal of personality assessment, vol. 82, no. 3, pp. 291-305, 2004.

[22] T. Sun, S. Youn, G. Wu, and M. Kuntaraporn, "Online word-of-mouth (or mouse): An exploration of its antecedents and consequences," Journal of Computer-Mediated Communication, vol. 11, no. 4, pp. 1104-1127, 2006.

[23] M. A. Belch, K. A. Krentler, and L. A. WillisFlurry, "Teen internet mavens: influence in family decision making," Journal of Business Research, vol. 58, no. 5, pp. 569-575, 2005.

[24] M. Laroche, F. Pons, N. Zgolli, M.-C. Cervellon, and C. Kim, "A model of consumer response to two retail sales promotion techniques," Journal of Business Research, vol. 56, no. 7, pp. 513-522, 2003.

[25] Meyliana, "Efektivitas implementasi dealer management system untuk meningkatkan csi dan ssi pada pt. indomobil trada nasional," in Prosiding Konferensi Nasional Teknologi Informasi dan Komunikasi (KNasTIK), 2010.

[26] Sugiyono, Metode Penelitian Bisnis. Bandung: CV Alfabeta, 2008. 
[27] W. L. Hays, Quantification in psychology. New Delhi: Prentice Hall, 1976.

[28] R. A. Julianto, R. Mahesa, A. P. W. C. Adim, and Meyliana, "Analisa perilaku pengguna dalam pen- erapan viral marketing pada 21cineplex," Bachelor Thesis, Universitas Bina Nusantara, Jurusan Sistem Informasi, April 2011. 